\title{
INVENTARIO KINÉSICO DEL QUIJOTE: CORPUS COMPLETO Y BASES PARA SU ESTUDIO
}

\author{
Fernando Poyatos
}

University of New Brunswick

\begin{abstract}
...has de saber, Sancho, si no lo sabes, que entre los amantes, las acciones y movimientos exteriores que muestran, cuando de sus amores se trata, son certísimos correos que traen las nuevas de lo que allá en lo interior del alma pasa (Quijote, $I I, X)$.
\end{abstract}

\section{INTRODUCCIÓN: LAS BASES PARA EL ESTUDIO DE LA KINÉSICA CERVANTINA ${ }^{1}$}

Como se hizo ya en esta revista para ofrecer un corpus completo de estudio para el paralenguaje cervantino en el Quijo-

1 Se ha utilizado la edición de Martín de Riquer (Barcelona: Juventud, 1965). Como fuente básica para desarrollar el estudio de este inventario e identificar y describir las 
$t e,{ }^{2}$ se recogen aquí todos los gestos, maneras y posturas que constituyen los repertorios kinésicos de los personajes ${ }^{3}$. Debo insistir de nuevo

conductas kinésicas, remito al lector a mi obra La comunicación no verbal, volumen I: Cultura, lenguaje e interacción; volumen II: Paralenguaje, kinésica e interacción; volumen III: Nuevas perspectivas en novela y teatro y en su traducción (Madrid: Ediciones Istmo, 1994; $2^{\mathrm{a}}$ ed. ampliada, en prep.); «Aspects, Problems and Challenges of Nonverbal Communication in Literary Translation», en F. Poyatos (ed.), Nonverbal Communication in Translation. 17-47 (Amsterdam/ Filadelfia: John Benjamins). En la pág. 135 del volumen III de La comunicación no verbal debe leerse «buena parte de las conductas kinésicas» donde por error dice «se registran todas las conductas kinésicas».

2 Desde ahora identificado como «El paralenguaje». Cf. Fernando Poyatos, «El paralenguaje en el Quijote: inventario completo y bases para su estudio». Signa 7 (1998), 293-318.

3 Kinésica: movimientos y posiciones de base psicomuscular conscientes o inconscientes, aprendidos o somatogénicos, de percepción visual, audiovisual y táctil o cinestésica, aislados o combinados con la estructura lingüística y paralingüística y con otros sistemas somáticos y objetuales, con valor comunicativo intencionado o no; es decir, todo movimiento externo y posición observables (gestos, respingos, tics, atusamiento de cabello), puesto que todos contribuyen a la imagen visual de la persona; también son kinésica las posturas simultáneas al movimiento (ej., los brazos cruzados, o la inclinación del cuerpo, al andar). Es indispensable identificar:

(a) la distinción entre gestos, maneras (no sólo «maneras» o modales personales o culturales, sino «la manera» como se realiza un gesto o una postura según cultura, sexo, nivel socieducacional, estado emocional, etc.), y posturas, de gran valor comunicativo, intercultural, social y personal;

(b) el carácter segmental de cualquiera de estas tres categorías como elementos del discurso (construyendo una frase verbal-no verbal) y de la interacción: ${ }_{i}$ Voto... $-y$ miró al cielo y apretó los dientes- que estoy por hacer un estrago en ti [...]!» (I, XXXVII);

(c) la coestructuración intersistémica, es decir, su relación con las palabras, el paralenguaje, el sonrojo, etc., incluso en una frase: «puestos los ojos en Quiteria, con voz tremente y ronca» (II, XXI);

(d) la coestructuración intrasistémica, es decir, dentro del mismo sistema kinésico: «con pasos quedos, el cuerpo agobiado y el dedo puesto sobre los labios» (II, XXXIII);

(e) las cualidades parakinésicas, que diferencian estilos personales y culturales (equivalentes a las paralingüísticas con relación al lenguaje verbal): intensidad, similar al acento y la tensión articulatoria: «Venía pisando quedito, y movía los pies blandamente» (II, XLVIII); campo, similar al alargamiento-acortamiento silábico: «una grande y profunda inclinación y reverencia» (II, XXXII); velocidad, similar al tempo del discurso: «y tornó a pasearse con el mismo reposo que primero (I, III), «con acelerada y nunca vista furia comenzó a llover cuchilladas» (II, XXVI); y duración: «mirando al suelo sin mover pestaña gran rato» (I, XXIII);

(f) el itinerario trifásico de cada conducta kinésica, que diferencia, por ejemplo, la ejecución de un gesto en culturas diferentes y según el nivel socioeconómico, sexo, edad, personalidad, etc., así como su ejecución en la época cervantina y ahora, aunque haya sobrevivido; se trata de una fase formativa, iniciada en diferentes posiciones para luego continuar su itinerario (constituyendo en realidad una «manera»); la central, sea un movimiento (abriendo y cerrando los dedos para significar «atestado», sacudiendo la mano durante un «O, là, là!» francés) o una posición estática (un guiño de flirteo, cogiéndose las sienes con índice y pulgar para hacer memoria, cruzado de brazos, etc.); y finalmente una fase desarticuladora antes de iniciarse la formativa del siguiente gesto o posición o, a menudo, fundiéndose con ella, lo que también constituye una «manera». 
en que su propósito no es simplemente la curiosidad de reunir todos los ejemplos de la kinésica del Quijote, sino promover el estudio de aspectos no estudiados hasta ahora sistemáticamente o, todo lo más, mencionados superficialmente y sin imponerse una perspectiva científica, ofreciendo un material susceptible de elaboración y de ser base de estudios similares para otros autores y épocas. Los fines de este artículo se resumen a continuación y deben verse como sugerencias para la elaboración de estudios cervantinos todavía inéditos y muy necesarios.

1. Juzgar la riqueza expresiva de los personajes cervantinos -reflejo del discurso de la época, excepto en casos de realismo distorsionante más allá del habla coloquial. Esta riqueza siempre puede disminuir la inevitable pluralidad de los personajes literarios en cada lectura y por cada lector.

2. Esa riqueza expresiva, al fin y al cabo tomada de la realidad, proporciona a la obra literaria diversos tipos de realismo que caracterizan a un autor y que identificamos ampliamente en el Quijote, entre ellos el que nos dejaría un fiel documento de cómo se ejecutaban ciertas acciones de la vida social ${ }^{4}$.

(g) finalmente, desde el punto de vista interactivo, es muy importante reconocer el carácter anticipatorio de las conductas kinésicas, ya que muy frecuentemente se inician visualmente antes que las palabras empiecen a expresar la misma idea: «puesta la mano en la espada y alzando los ojos al cielo, dijo:/ _-Yo hago juramento al Criador de todas las cosas (I, X).

4 Encontramos los siguientes tipos de realismo:

Realismo físico personal (otro sería el «ambiental»): «Miró también don Quijote a Sancho, y vióle que tenía los carrillos hinchados, y la boca llena de risa, con evidentes señales de querer reventar con ella [...] y [...] Sancho [...] soltó la presa de tal manera que tuvo necesidad de apretarse las ijadas con los puños, por no reventar riendo» (I, XX).

Realismo deformante, en el que encontramos la distorsión de lo que consideramos posible: «Sancho [...] se echó entrambos puños a las barbas, y se arrancó la mitad de ellas, y luego, apriesa y sin cesar, se dio media docena de puñadas en el rostro y en las narices, que se las bañó todas en sangre (I, XXVI).

Realismo individualizador, que en el caso de la kinésica y el paralenguaje nos ayuda a construir una figura única (frente a la posible indiferenciación no infrecuente en la narrativa menos valiosa), a través de rasgos interactivos y reacciones situacionales que ya esperamos: $\ll$ Oh, bellaco, villano, mal mirado [...]! Y diciendo esto [don Quijote], enarcó las cejas, hinchó los carrillos, miró a todas partes, y dio con el pie derecho una gran patada en el suelo (I, XLVI), «don Quijote [...] con semblante airado y alborotado rostro, se puso en pie y dijo...» (II, XXXI).

Realismo psicológico: «Paróse Sancho Panza a rascar la cabeza, para traer a la memoria la carta, y ya se ponía sobre un pie, y ya sobre otro; unas veces miraba 
3. Por otra parte (como confirma la cita que encabeza este artículo), el análisis de este inventario nos permite aquilatar la importancia concedida por Cervantes a la expresividad kinésica - mucho más de lo que encontramos, por ejemplo, en las novelas picarescas- y el grado en que nos ofrece un repertorio de la vida cotidiana, identificando reglas de urbanidad, modos de comer y beber diferenciados socialmente, etc., como lo que se acaba de denominar «realismo documental».

4. Identificar la presencia explícita de los fenómenos kinésicos en el Quijote, reconociendo que, sin mediar descripción alguna del paralenguaje, también existe éste asociado a esas conductas kinésicas (lo mismo que el paralenguaje descrito o representado evoca la kinésica); sobre todo en casos de expresiones en que, por la perfecta cohesión existente dentro de la triple estructura lenguajeparalenguaje-kinésica de nuestro hablar, esos tres sistemas básicos del discurso se combinan en patrones fijos propios del lenguaje coloquial de todos conocido (personal y cultural o subculturalmente diferenciadas); por ejemplo, en «Decía esto con tanto brío y denuedo», «con reposo y ademán severo», mientras que el tipo de voz puede evocar los aspectos visuales del discurso ${ }^{5}$.

5. Por otra parte, debemos reconocer que esas descripciones verbales de la kinésica no siempre son suficiente para que el lector «vea» correctamente los movimientos corporales de esas personas del siglo XVII con quienes convivía Cervantes y a quienes él retrataba mucho más eficazmente para sus lectores coetáneos, actores de esos movimientos y posturas (con excepción de cier-

al suelo, otras al cielo, y al cabo de haberse roído la mitad de la yema de un dedo [...] (I, XXVI), Oyó Cardenio el nombre de Luscinda, y no hizo otra cosa que encoger los hombros, morderse los labios, enarcar las cejas, y dejar de allí a poco caer por sus ojos dos fuentes de lágrimas» (I, XXVIII).

Realismo interactivo, reflejado en la veracidad de los interrcambios personales verbales y no verbales y a las reacciones explícitas e implícitas a las conductas y pensamientos de unos y otros. Véase nota 9.

Realismo documental: «Y poniéndose de rodillas [el labrador], le pidió la mano para besársela\} (II, XLVII), «cada bocado, que le tomaban con la punta del cuchillo, y muy poquito de cada cosa [...] levantaron los brazos y las botas en el aire; puestas las bocas en su boca, clavados los ojos en el cielo [...] meneando las cabezas a un lado y a otro, señales que acreditaban el gusto que recebían» (II, LIV).

5 Para intuir esta presencia del paralenguaje, el lector puede repasar el esquema del paralenguaje que se da en la nota 2 de «El paralenguaje». 
tos conductas de la desaparecida caballería andante, no por eso carente de residuos sociales y documentación) que nosotros, alejados cada vez más en el espacio y en el tiempo. Cómo se dijo del paralenguaje, qué no daríamos, en este caso, por saber cómo era exactamente aquel «gentil talante», aquel «con muestras de algún despecho», aquel hablar «con ademán arrogante», aquel «les hizo señas de que le siguiesen», o el hablar «con muestra de ánimo indignado», actitudes que formalmente pueden variar en algo. Por otra parte, sabemos que la kinésica ha sido condicionada a través de los siglos por el vestido, así como por la evolución de la moral, las relaciones sociales, las normas de etiqueta, etc. ${ }^{6}$

6. Vemos que muchos gestos, maneras y posturas han perdurado hasta nuestros días: «dijo, meneando la cabeza a una parte y a otra:/ — ¡Ay señor, señor [...]» (I, XLVI), «Uno [...], puesto un dedo en la boca, en señal de que callase [don Quijote]» (II, LXVIII).

7. Por otra parte, el hecho de que parezcan haberse conservado no quiere decir que perduren con exactamente las mismas cualidades parakinésicas (véase nota 2), sino tal vez sólo básicamente, por ejemplo, el citado más arriba, o «Decía esto Sancho con tanto reposo, limpiándose de cuando en cuando las narices, y con tan poco juicio» (I, XXVI).

8. Otros, en cambio $-y$, como se ha dicho, incluso condicionados o desterrados por la ropa o por diversas causas sociales-, se han perdido, por ejemplo: «Y luego, descalzándose un guante, le arrojó en mitad de la sala [en señal de desafío]» (II, LII); «[don Quijote, preguntando sobre la carta que dio a Sancho para Dulcinea] cuando le diste mi carta, ¿besóla? ¿Púsosela sobre la cabeza?» (I, XXXI); para significar que uno «no tiene una perra,» como diríamos hoy, o sacándonos el forro de los bolsillos del pantalón: «[Sancho] poniéndose el dedo pulgar en la garganta y extendiendo la mano arriba, les dio a entender que no tenía ostugo de moneda» (II, LIV).

6 Véase, entre otras fuentes (y ésta estudia conductas importadas de la corte espanola), Joan Wildeblood, The Polite World: A Guide to English Manners and Deportment From the Thirteen to the Nineteenth Century. London: Oxford University
Press, 1965. 
9. También pretende este inventario suscitar más investigación en otro campo aún virgen, pese a las dificultades a veces insuperables de tal empresa reconstructiva: la evolución del español hablado en su totalidad verbal-paralingüística-kinésica, atendiendo a las causas y circunstancias histórico-sociales que han determinado la aparición, evolución o desaparición de formas verbales, paralingüísticas y kinésicas.

10. No hay que descartar, claro está, que, así como se han conservado en Hispanoamérica vocablos del habla diaria de España, se hayan conservado también algunos gestos, maneras y posturas. Sin embargo, es imposible verificar si alguno de esos actos kinésicos se ejecutaban con alguna característica hoy desaparecida, aunque sea prácticamente el mismo formal y semánticamente.

11. Estas descripciones del cómo se mueve lo que se dice (a veces junto con el cómo se dice o paralenguaje) nos sugieren inmediatamente el escollo tan grande con que se enfrenta el lector extranjero del texto traducido, en el cual el traductor debe ejercer un cuidado extremado al escoger las palabras que describen cada conducta con los mismos matices semánticos que las originales; lo cual dependerá también en gran parte de la formas semiótico-comunicativas (identificadas a continuación) que el escritor haya utilizado en sus descripciones ${ }^{7}$.

12. Por tanto, el estudio de las conductas kinésicas también debe servir al estudioso de Cervantes para reconocer esas funciones semiótico-comunicativas, e incluso técnicas, de las descripciones kinésicas, teniendo en cuenta las dificultades de descodificación a través del tiempo (en épocas posteriores) y del espacio

7 A veces se planteará la posibilidad de ayudar a sus lectores con una nota explicativa en el caso de conductas culturales desconocidas para ellos, o incluso la muy cuestionable libertad de añadir palabras que expliquen mejor el significado de una acción kinésica, como único recurso para una descodificación correcta. Véanse ejemplos de esta intervención en Pierangela Diadori, «The Translation of Gestures in the English and German Versions of Manzoni's I Promessi Sposi», en F. Poyatos (ed.), Nonverbal Communication in Translation (Amsterdam/ Filadelfia: John Benjamins, 1997, 132149); también los comentarios sobre la traducción en F. Poyatos, «Aspects, Problems and Challenges of Nonverbal Communication in Literary Translation» (en el mismo volumen, 17-47), así como las muchas referencias a la traducción en Poyatos, 1994, volumen III. 
(en su traducción intercultural, expuesta a lo que podemos llamar «falsos cognados culturales»). ${ }^{8}$

13. Como en otros narradores de ésa y otras épocas de la sociedad española -y de otras, con interasantísimas semejanzas, como en la misma kinésica-, el Quijote nos documenta ciertas funciones interactivas de los comportamientos kinésicos idénticas a las de nuestros días en distintas culturas, para cuyo estudio (parte indispensable si se trata la comunicación no verbal en el Quijote de manera exhaustiva) habría que observar no sólo las reacciones causa-efecto (i.e., reacción verbal o como verdadero «exteriorizador»), sino incluso respecto de lo no ocurrido aún, como expectación: «Parecióle a Dorotea que don Fernando había perdido la color del rostro y que hacía ademán de querer vengarse de Cardenio porque le vio encaminar la mano a ponella en la espada, y así como lo pensó, con no vista presteza se abrazó con él por las rodillas» (I, XXXVI).

Indudablemente, es ésta una perspectiva enriquecedora para salir de los caminos más trillados de la investigación cervantina y literaria en general ${ }^{9}$.

14. Una característica importante de la técnica cervantina al proporcinarnos las conductas kinésicas que forman parte del discurso de sus personajes es que en la mayoría de los casos esa

${ }^{8}$ Estos procedimientos semiótico-comunicativos son:

Describiendo la conducta y explicando su significado (significante y significado): «Y diciendo esto, dio [Sancho] dos zapatetas en el aire, con muestras de grandísimo contento" (I, XXX).

Describiendo la conducta, pero no su significado (significante y no significado): conductas kinésicas de otra época histórica que no han perdurado; o de otra cultura que, en el peor de los casos, nos ofrece algunos de sus falsos cognados kinésicos (homomorfos que no son sinónimos): «miré la ventana, y vi que por ella salía una muy blanca mano; que la abrían y cerraban muy apriesa» (I, XL).

Explicando el significado sin describir la conducta (significado, pero no significante): «Sancho [...] sacó de sus alforjas medio pan y medio queso [...] diciendo por señas que no tenía otra cosa que darles» (II, LIV)

Dando sólo la expresión verbal cuando siempre va acompañada de una no verbal, que es la que completa el mensaje, conducta kinésica de otro época hoy no subsistente en la cultura del lector: «iDos higas para el Gran Capitán y para ese Diego García que dice!» (I, XXXI).

9 Para el estudio de la interacción, y concretamente de la conversación, véanse dos modelos detallados (con ejemplos literarios españoles y extranjeros) en $\mathrm{La}$ comunicación no verbal, vols. I, I, respectivamente. 
conducta kinésica o paralingüística la leemos antes de las palabras que acompañan (y que tal vez califican elocuentemente). Esto nos permite «ver» y «oír» los componentes verbales y no verbales del habla en perfecta sincronización, lo que no ocurriría si, como encontramos en la mayoría de los autores, nos enteráramos del cómo se dice después de oír lo que se dice, lo que siempre resta realismo a una lectura ${ }^{10}$.

15. En kinésica cabe una posible dimensión prácticamente inexistente en épocas más lejanas: la artística, en pintura, grabado y escultura. En épocas posteriores, como sería la de un Galdós, ya encontrariamos el documento gráfico de la pintura figurativa más realista (a la par del realismo literario), y a continuación el de la fotografía, los cuales nos permiten cotejar descripciones literarias de gestos y maneras (descritos verbalmente en su «fase central» más significativa) y de posturas (al ser sobre todo estáticas, descritas en su fase menos susceptible de ambigüedad) ${ }^{11}$.

\section{ORGANIZACIÓN DEL INVENTARIO}

El inventario consta de tres secciones fundamentales: «Gestos», «Maneras» $\mathrm{y}$ «Posturas», y, dentro de cada grupo, se distinguen diversas categorías no verbales ${ }^{12}$. Las citas están ordenadas en cada apar-

10 Véase, como estudio más reciente, «El acto de lectura: su realidad verbal-no verbal», El Extramundi y los Papeles de Iria Flavia,

11 Recuérdese, por ejemplo, la riqueza de la iconografía cristiana, tanto en pintura y escultura como en tratados y manuales sobre la liturgia y la oración. Véase (además por su rica bibliografía), Jean-Claude Schmitt, La raison des gestes dans l'Occident médiéval (Paris: Gallimard, 1990), y, por el mismo autor, «The Rational of Gestures in the West: A History from the 3rd to the 13th centuries», en F. Poyatos (ed.), Advances in Nonverbal Communication: Sociocultural, Clinical, Esthetic and Literary Perspectives (Amsterdam/ Filadelfia: John Benjamins, 77-95). Véase el sugerente artículo (ilustrado) sobre la comunicación no verbal en arte, desde el egipcio hasta la pintura anecdótica del XIX, de E. H. Gombrich, «Action and Expression in Western Art», en R. Hinde A. Hinde (ed.), Nonverbal Communication (Cambridge: Cambridge University Press, 1972, 373-394, 422-423).

12 Según el modelo «Nonverbal Categories as Personal and Sociocultural Identifiers,» en P. Bouissac, M. Herzfeld, R. Posner (eds.), Iconicity: Essays on the Nature of Culture. Festschrift for Thomas A. Sebeok on His 65th Birthday (Tübingen: Stauffenburg Verlag, 1986, 469-525), una ampliación del sugerido por Ekman y Friesen, «The Repertoire of Nonverbal Behavior: Categories, Origin, Usage and Coding», Semiotica 1 (1969), 49-98. En el Quijote aparecen sólo las siguientes categorías, aquí 
tado en el orden en que aparecen en el libro. Respecto de la organización de estos apartados deben hacerse las siguientes aclaraciones:

a) Puesto que las diversas categorías no verbales no se excluyen mutuamente, hay citas que se encuentran repetidas bajo más de una categoría, por ejemplo, «les echó la bendición» aparece como emblema (sustituto de una expresión verbal concreta) y como alteradaptador. No se abusa, sin embargo, de estas repeticiones, y así, por ejemplo, «Oyendo esto Sancho, se arrimó sobre el espaldar de la silla y miró de hito en hito al tal médico» se ubica solamente como gesto exteriorizador, aunque alguien pudiera considerarlo como un emblema de asombro. Por otra parte, aunque las repeticiones impiden al lector del inventario ver la secuencia ininterrumpida de todas los ejemplos de kinésica a través de la obra (para lo cual el investigador puede reunirlas fácilmente si lo necesita), esta organización no es precisamente gratuita puesto que sugiere la posible identificación de ciertos patrones, no sólo culturales (ej., alteradaptadores de contacto físico interpersonal, que no encontramos en el mismo grado en otras culturas), sino también sociales (ej., la manera de beber de la bota, «el andar a caballo a unos hace caballeros», «Anda despacio») e históricos (ej., «le hizo una mamona muy bien sellada, y luego una gran reverencia»); y también a veces la sorprendente diferencia en la frecuencia de estas conductas entre la primera y segunda parte de la obra.

b) Conviene insisistir en la presencia implícita del paralenguaje en casos en que la conducta kinésica ocurre como parte del discurso (lo mismo que la mayoría de las conductas paralinguísticas conlleva una kinésica inherente a ellas); naturalmente, hay algu-

\footnotetext{
definidas muy escuetamente: emblema: acto kinésico con un equivalente verbal concreto, no ambiguo; exteriorizador: una reacción a la realidad nuestra o de otros, presente, pasada, anticipada o imaginada, a lo dicho o hecho, o silenciado o no hecho, y a sucesos reales o imaginados, y a experiencias psíquicas, somáticas, estéticas, espirituales o ambientales; autoadaptador: contacto con nosotros mismos; alteradaptador: contacto con otras personas o animales (tan humanizados en el Quijote), pero también (según el concepto de «articulación interactiva» [La comunicación no verbal, vol. I, 79-80) sin llegar a tocar, por ser un contacto visual (ej., «con los brazos abiertos, fue a abrazar»); objetoadaptador: contacto con un objeto y el objeto mismo; somatoadaptador; contacto y experiencia con la realidad material más íntimamente asociada al cuerpo (comida, bebida, ropa, armas, mobiliario anatómico) y esos objetos y substancias mismos.
} 
nos compuestos paralingüístico-kinésicos que se registraron ya en el Inventario Paralinguiístico.

Las referencias de Cervantes a la conducta kinésica, contadas sin ninguna repetición, alcanza la cifra de

\section{INVENTARIO KINÉSICO DEL QUIJOTE}

\section{A. Gestos}

\section{Emblemas}

\section{Primera Parte}

Oyendo lo cual, mi amigo, dándose una palmada en la frente y disparando en una carga de risa, me dijo:/ -Por Dios, hermano, que ahora me acabo de desengañar de un engaño (I, «Prólogo»).

apretó la lanza, llegó la adarga al pecho y, puesto en la mitad del camino [...] levantó don Quijote la voz y con ademán arrogante dijo: / Todo el mundo se tenga, si todo el mundo no confiesa que no hay en el mundo doncella más hermosa que [...] Dulcinea del Toboso (I, IV)

[don Quijote] se llegó a él [el vizcaíno], y poniéndole la punta de la espada en los ojos, le dijo que se rindiese (I, IX)

[el Roto] Como acabó de comer, les hizo señas de que le siguiesen (I, XXIV)

[Sancho Panza, al despedirse de don Quijote] pidió la bendición a su señor, $\mathrm{y}$, no sin muchas lágrimas de entrambos, se despidió dél (I, XXV) ${ }^{13}$

13 Debe quedar claro que el estudio completo de la comunicación no verbal personal (aparte de la ambiental), debe incluir los otros canales somáticos de transmisión de signos y mensajes (véase La comunicación no verbal, vol. I, cap. II, y cuanto sobre 
el cura, que iba delante, hizo señas a los otros que se agazapasen (I, XXVIII)

y después que se la hubo besado [la mano Sancho], le echó [don Quijote] la bendición (I, XXX)

\section{¡Dos higas para el Gran Capitán y para ese Diego García que dice!} (I, XXXII) ${ }^{14}$

y puestas entrambas manos cruzadas sobre el pecho [la mora embozada], inclinada la cabeza, dobló el cuerpo en señal de que lo agradecía (I, XXXVII) ${ }^{15}$

ellos incluye el volumen III, dedicado a la literatura). Independiente de los ejemplos incluidos en «El paralenguaje», encontramos aquí el primero de reacción química en la lágrimas, con la función semítico-comunicativa e interactiva correspondiente. Para reacciones dérmicas, véase nota 17 . Otros signos somáticos, siempre con funciones interactivas (puesto que la percepción sensible va siempre seguida de la intelectual) son: forma, tamaño, consistencia, peso y color de piel, pelo y ojos.

14 (De nuevo en II, XXXI). Una expresión despreciativa que desde la antigüedad se acompañaba de un gesto: mostrando el pulgar entre el índice y el medio con el puño cerrado, primero como manera de ahuyentar al demonio y el mal de ojo, luego también como menosprecio o insulto, y que aún se vende como amuleto en forma de dije. En nuestros clásicos la encontramos, por ejemplo, en la Vida de Santa Teresa: «y ¡una higa para todos los demonios!» (XXV.22); en La Dorotea, de Lope: «»Otra vez te vuelvo a dar higas» (II, iv); en una letrilla de Góngora en la que fustiga diversas necedades humanas (al modo del «arancel de necedades» del Guzmán de Alfarache, de Mateo Alemán), describiéndolas en cada una de sus nueve estrofas y asignándoles, como estribillo, de «una higa» a «nueve higas», ej.: «Al que pretende más salvas. Y ceremonias mayores/ Que se deben por señores/ A las Infantados y Albas,/ Siendo nacido en las malvas, / Y criado en las hortigas, / Cinco higas». En Shakespeare (además de en The Merry Wives of Windsor y The Second Part of Henry VI), en The Second Part of Henry IV: «Pistol. [...] Harry the Fifth's the man. I speak the truth./ When Pistol lies, do this, and fig me, like/ The bragging Spaniard» (V, III), y en Henry V: «Pistol. Die and be damned! and a figo for thy friendship! [...] The fig of Spain!» (III, VI) (ya que se decía ser una expresión española); en el Martin Chuzzlewit, de Dickens, tras enumerar todos los inconvenientes de un "gig," o calesa, el personaje dice: «A fig for gigs!» (XII). Es de suponer (sobre todo en Santa Teresa) que no siempre se acompañaba la expresión verbal del gesto. Como han estudiado (como atlas kinésico en los 70 a través de Europa) Morris et al. (Gestures: The Origins and Distribution (Nueva York: Stein and Day, 1979: 147-160) es hoy un gesto polisémico («the fig,» «la higa,» «la fica,» «la figue») como referencia, insulto sexual, protector, etc. Sin poder asegurar que sea necesariamente un préstamo, se conoce con connotación sexual en otras latitudes, por ejemplo, en Hong Kong y Venezuela. Para otras referencias a obras literarias españolas clásicas y al Tesoro de la lengua española $o$ castellana, de Sebastián de Covarrubias (1611), véase la amplia nota 5 al capítulo XXXI de la segunda parte del Quijote, en la edición de Rodríguez Marín (Madrid, 1948).

15 Los ejemplos de la kinésica sin palabras de Zoraida corresponden a los repertorios que ha estudiado José Romera Castillo en «Repertorios extraverbales en la comunicación literaria», Signa 3 (1994), 175-208; «Rasgos kinésicos en el Diario de Cristóbal Colón», en M. Criado (ed.), Literatura Hispánica. Reyes Católicos y Descubrimiento (Barcelona: PPU, 1989, 115-124) y «Gestos y ojos hablan en Soneta de Primavera», Revista de Estudios Hispánicos (Universidad de Puerto Rico), XVI (1989, 45-51. 
miré la ventana, y vi que por ella salía una muy blanca mano; que la abrían y cerraban muy apriesa (I, XL)

en señal de que lo agradecíamos hecimos zalemas a uso de moros, inclinando la cabeza, doblando el cuerpo y poniendo los brazos sobre el pecho (I, XL)

hicimos todos nuestras zalemas (I, XL)

Hice señas [a quien se ocultaba en una ventana] que leería el papel (I, XL)

«[...] tú cristiano, busca tus yerbas, y vete en buen hora [...]. Yo me incliné, y él [el padre de Zoraida] se fue (I, XLI)

entre las señas que me hacía [la mora desde su ventana], era una de juntarse la una mano con la otra, dándome a entender que se casaría conmigo (I, XLIII)

Cuando el canónigo oyó hablar al preso y al libre en semejante estilo, estuvo por hacerse la cruz de admirado (I, XLVII).

\section{Segunda Parte}

[Quiteria] puesta de rodillas, le pidió [a Basilio] la mano por señas, y no por palabras (II, XXI)

asidos de las manos Basilio y Quiteria, el cura, tierno y lloroso, les echó la bendición (II, XXI)

¿No ven aquel moro que callandico y pasito a paso, puesto el dedo en la boca, se llega por las espaldas de Melisendra? [para besarla de improviso] (II, XXVI)

- Hermano, si sois juglar — repitió la dueña-, guardad vuestras gracias para donde lo parezcan y se os paguen; que de mí no podréis llevar sino una higa [dicho con un gesto despreciativo] (II, XXXI)

[don Quijote] haciendo una profunda reverencia a los duques, como que les pedía licencia para hablar (II, XXXII)

[cuando la duquesa le hace sentarse, aunque no quería por cortesía] Encogió Sancho los hombros, obedeció y sentóse (II, XXXIII) 
Sancho [...] con pasos quedos, el cuerpo agobiado y el dedo puesto sobre los labios, anduvo por toda la sala levantando los doseles por si les veía alguien (II, XXXIII)

baje vuestra merced esa vara [para jurar sobre ella]; y [...] yo juraré [...] (II, XLV)

Bajó el gobernador la vara [para jurar sobre ella] [...] el viejo [...] puso la mano en la cruz de la vara, diciendo que era verdad que (II, XILV)

uno que parecía estudiante echó la bendición [sobre la mesa del gobernador] (II,XLVII)

Hizo de señas el maestresala al labrador que se saliese de la sala (II, XLVII)

Y luego, descalzándose un guante, le arrojó en mitad de la sala, y el duque se alzó, diciendo que, como ya había dicho, él acetaba el tal desafío (II, LII)

[Sancho] entendió que le pedían dineros; y él, poniéndose el dedo pulgar en la garganta y extendiendo la mano arriba, les dio a entender que no tenía ostugo de moneda (II, LIV)

[tras ver en la imprenta una segunda parte del Quijote de Avellaneda y hablar sobre ella] diciendo esto, con muestras de algún despecho, se salió de la imprenta (II, LXII)

[tras derribar el de la Blanca Luna a don Quijote] Fue luego sobre él, y poniéndole la lanza sobre la visera, le dijo:/ - Vencido sois, caballero (II, LXIV)

[el de la Blanca Luna] haciendo mesura [reverencia] con la cabeza al visorrey, a medio galope se entró en la ciudad (II, LXIV)

«Uno [...], puesto un dedo en la boca, en señal de que callase [don Quijote]» (II, LXVIII)

sentaron a don Quijote y a Sancho [...] dándoles a entender con señales a los dos que asimismo callasen (II, LXIX).

\section{Exteriorizadores}

\section{Primera Parte}

levantando don Quijote la voz y con ademán arrogante dijo:/ Todo el mundo se tenga, si todo el mundo no confiesa que no hay en el mundo doncella más hermosa que [...] Dulcinea del Toboso (I, IV) 
Estando en lo mejor de su plática, paró, y enmudecióse; clavó los ojos en el suelo por un buen espacio [...] por lo que hacía de abrir los ojos, estar fijo mirando al suelo sin mover pestaña gran rato, y otras veces cerrarlos, apretando los labios y enarcando las cejas, fácilmente conocimos que algún accidente de locura le había sobrevenido (I, XXIII)

y luego [don Quijote], sin más ni más, dio dos zapatetas en el aire y dos tumbas [volteretas] la cabeza abajo y los pies en alto (I, XXV)

Oyó Cardenio el nombre de Luscinda, y no hizo otra cosa que encoger los hombros, morderse los labios, enarcar las cejas, y dejar de allí a poco caer por sus ojos dos fuentes de lágrimas (I, XXVIII)

$Y$ diciendo esto, dio [Sancho] dos zapatetas en el aire, con muestras de grandísimo contento (I, XXX)

La hija callaba y de vez en cuando se sonreía (I, XXXV)

¡Voto...-y miró al cielo y apretó los dientes-que estoy por hacer un estrago en ti [...]! (I, XXXVII)

y cuando, por habernos hecho a la vela, no podimos oír sus palabras [el padre de la mora], vimos sus obras, que eran arrancarse las barbas, mesarse los cabellos y arrastrarse por el suelo (I, XLI)

Zoraida, aunque no entendía bien todos los sucesos que había visto, se entristecía y alegraba a bulto, conforme veía y notaba los semblantes a cada uno (I, XLVI)

fue tanto [el enojo de don Quijote] que, con voz atropellada y tartamuda lengua, lanzando vivo fuego por los ojos, dijo: ;Oh, bellaco, villano, mal mirado [...]! Y diciendo esto, enarcó las cejas, hinchó los carrillos, miró a todas partes, y dio con el pie derecho una gran patada en el suelo, señales todas de la ira que encerraba en sus entrañas (I, XLVI).

\section{Segunda Parte}

Las maldiciones que las dos, ama y sobrina [...] mesaron sus cabellos, arañaron sus rostros, y al modo de las endechaderas [plañideras de alquiler] que se usaban, lamentaban la partida como si fuera la muerte de su señor (II, VII) 
se había puesto don Quijote de hinojos [ante la labradora] junto a Sancho, y miraba con ojos desencajados y vista turbada a la que Sancho llamaba reina y señora (II, X)

Llegó Sancho, y como vio el rostro del bachiller Carrasco, comenzó a hacerse mil cruces y a santiguarse otras tantas (II, XIV)

[cuando Quiteria le pide la mano por señas] Desencajó los ojos Basilio, y mirándola atentamente, le dijo:/ —iOh Quiteria [...]! (II, XXI)

[don Quijote] mirando a una y otra parte, como espantado, dijo:/ Dios os lo perdone, amigos; que me habéis quitado de la más sabrosa y agradable vista que ningún humano ha visto ni pasado (II, XXII)

[en las marionetas de Maese Pedro] aquel moro [...] le da un beso en mitad de los labios [a Melisendra], y la priesa que ella se da a escupir, y a limpiársela con la blanca manga de su camisa, y cómo se lamenta, y se arranca de pesar sus hermosos cabellos (II, XXVI)

viendo a la dueña tan alborotada y tan encarnizados los ojos (II, XXXI)

don Quijote [...] con semblante airado y alborotado rostro, se puso en pie y dijo... Pero esta respuesta capitulo por sí merece (II, XXXI)

Oyendo esto Sancho, se arrimó sobre el espaldar de la silla y miró de hito en hito al tal médico (II, XLVII)

Volvióse don Quijote a Sancho, y encendido el rostro y colérico, le dijo:/ — ¿Es posible, ¿oh Sancho!, que haya en todo el orbe alguna persona que diga que no eres tonto [...]? (II, LVIII) ${ }^{16}$

El silencio fue allí el que habló por los dos amantes, y los ojos fueron las lenguas que descubrieron sus alegres y honestos pensamientos (II, LXV)

A cuyos ofrecimientos abrió Sancho los ojos y las orejas de un palmo (II, LXXI)

Sancho [ante el moribundo don Quijote] empezó a hacer pucheros y a derramar lágrimas] (II, LXXIV).

16 Primer ejemplo de reacción dérmica, percibida visualmente. Otros pueden incluir otras descripciones verbales: «el rostro se le cubrió de un color que mostró bien claro el sentimiento y vergüienza del alma». 


\section{Autoadaptadores}

\section{Primera Parte}

Oyendo lo cual, mi amigo, dándose una palmada en la frente y disparando en una carga de risa, me dijo:/ -Por Dios, hermano, que ahora me acabo de desengañar de un engaño (I, «Prólogo»)

apenas hubieron llegado [los vapores de Sancho a las narices de don Quijote], cuando él fue al socorro, apretándolas entre los dos dedos, y con tono algo gangoso, dijo: [...] todo esto sin quitarse los dedos de las narices $(\mathrm{I}, \mathrm{XX})$

y luego, sin más ni más, dio dos zapatetas en el aire y dos tumbas [volteretas] la cabeza abajo y los pies en alto (I, XXV)

$Y$ diciendo esto, dio [Sancho] dos zapatetas en el aire, con muestras de grandísimo contento (I, XXX)

cuando [Lotario, tras encontrar a Camila herida]] se vio solo y en parte donde nadie le veía, no cesaba de hacerse cruces, maravillándose de la industria de Camila y de los ademanes tan propios de Leonela (I, XXXIV)

Y [Trifaldín el de la Barba Blanca] tosió luego y manoseóse la barba de arriba abajo con entrambas manos, y con mucho sosiego estuvo atendiendo la respuesta del duque (II, XXXVI)

Y por no oílle [Clara], se tapó con las manos entrambos oídos (I, XLIII).

\section{Segunda Parte}

Y dando [maese Pedro] con la mano derecha dos golpes sobre el hombro izquierdo, en un brinco se le puso el mono en él (II, XXV)

El mozo se quitó la montera y, sacudiendo la cabeza a una y a otra parte, se comenzaron a descoger y desparcir unos cabellos que pudieran los del sol tenerles envidia (I, XXVIII) 
Diose don Quijote una gran palmada en la frente, y comenzó a reír muy de gana [de Sancho], y dijo: (II, XXVIII)

[Sancho] entendió que le pedían dineros; y él, poniéndose el dedo pulgar en la garganta y extendiendo la mano arriba, les dio a entender que no tenía ostugo de moneda (II, LIV)

Hizo señal el cómitre que zarpasen el ferro [levasen el áncora] (II, LXIII)

Uno [...] puesto un dedo en la boca, en señal de que callase [don Quijote] (II, LXVIII)

[doña Rodríguez] vio la prisa con que se estaba haciendo cruces don Quijote (II, XLVIII).

Alteroadaptadores

Primera Parte

[don Quijote] llegándose a él [el encamisado derribado por él de su mula], le puso la punta del lanzón en el rostro, diciéndole que se rindiese; si no, que la mataría (I, XIX).

Objetoadaptadores

Primera Parte

[don Quijote, preguntando sobre la carta que dio a Sancho para Dulcinea] cuando le diste mi carta, ¿besóla? ¿Púsosela sobre la cabeza? [se hacía con carta de persona muy importante, por respeto] (I, $\mathrm{XXXI)}$

y al cabo de lo escrito hecha una grande cruz. Besé la cruz (I, XL). 


\section{Segunda Parte}

Y diciendo esto, echó mano a su espada y comenzó a esgrimirla en el aire contra los molineros (II, XXIX)

yendo [...] a besarle [a una dama] las manos, y a recebir su bendición, beneplácito y licencia para esta tercera salida (II, XXXII)

Bajó el gobernador [Sancho] la vara [para prestar el viejo juramento sobre ella] (II, XLV).

\section{B. Maneras}

\section{Exteriorizadores}

\section{Primera Parte}

[al llegar don Quijote ante las mozas de la venta] alzándose la visera de papelón y descubriendo su seco y polvoroso rostro, con gentil talante y voz reposada les dijo:/ - No fuyan las vuestras mercedes ni teman desaguisado (I, II)

[don Quijote a aquellas mozas de la venta, imaginándolas] principales señoras y damas de aquel castillo, les dijo con mucho donaire:/ Nunca fuera caballero de damas tan bien servido [...] (I, II)

vieron que [don Quijote], con sosegado ademán, unas veces se paseaba (I, III)

[don Quijote, antes de atacar al arriero que maltrataba al muchacho] alzó los ojos al cielo y, puesto el pensamiento - a lo que pareció- en su señora Dulcinea, dijo:/ - Acorredme, señora mía, en esta primera afrenta que a este vuestro avasallado pecho se le ofrece (I, III)

[don Quijote] recogió sus armas y tornó a pasearse con el mismo reposo que primero (I, III)

Decía esto [don Quijote] con tanto brío y denuedo, que infundió un terrible temor en los que le acometían (I, III) 
[don Quijote] con muestras de grande sentimiento se comenzó a volcar [revolcar] por la tierra, y a decir con debilitado aliento [...]:/ ¿Dónde estás, señora mía, que no te duele mi mal? (I, V)

puesta la mano en la espada y alzando los ojos al cielo [don Quijote], dijo:/ - Yo hago juramento al Criador de todas las cosas (I, X)

[Ambrosio a Marcela] con muestra de ánimo indignado le dijo:/ - iVienes a ver, por ventura, joh fiero basilisco destas montañas! [...]? (I, XIV)

[don Quijote, tras beberse el bálsamo] comenzó a vomitar [...] y con las ansias y agitación del vómito le dio un sudor copiosísimo (I, XVII)

[a Sancho, tras beber el bálsamo] primero que vomitase, le dieron tantas ansias y bascas, con tantos trasudores y desmayos que [..] (I, XVII)

enristró su lanzón, púsose bien en la silla, y con gentil brío y continente se puso en la mitad del camino (I, XIX)

Don Quijote [...], apeándose de Rocinante, con gentil continente y donaire [yendo a abrazar al mancebo] (I, XXIII)

Y después que los tuvo a todos rendidos y molidos, les dejó, y se fue, con gentil sosiego, a emboscarse en la montaña (I, XXIV)

diciendo esto [Sancho] dio dos zapatetas en el aire, con muestras de grandísimo contento (I, XXX)

Sancho [...] levantándose con un poco de presteza, se fue a poner detrás del palafrén de Dorotea (I, XXX)

[se paseaba por la sala con la daga desenvainada, dando tan desconcertados y desaforados pasos y haciendo tales ademanes, que no parecía sino que le faltaba el juicio (I, XXXIV)

[Dorotea] con ademán señoril y acomodado al estilo de don Quijote, le respondió de esta manera [...] (I, XLVI)

[don Quijote, al verse fuera de la jaula] lo primero que hizo fue estirarse todo el cuerpo (I, XLIX).

\section{Segunda Parte}

ya se había puesto don Quijote de hinojos junto a Sancho, y miraba con ojos desencajados y vista turbada a la que Sancho llamaba reina y señora [una aldeana] (II, X, 606) 
Anda despacio; habla con reposo (II, XIII)

el licenciado [en un duelo], con gentil donaire de cuerpo y compás de pies, se iba contra Corchuelo (II, XIX)

Despertó, en fin, soñoliento y perezoso (II, XX)

[don Quijote] con acelerada y nunca vista furia comenzó a llover cuchilladas sobre la titerera morisma (II, XXVI)

Don Quijote, alzando la visera, con gentil brío y continente, llegó hasta el estandarte del asno (II, XXVII)

y cuando, por habernos hecho a la vela, no podimos oír sus palabras [el padre de la mora], vimos sus obras, que eran arrancarse las barbas, mesarse los cabellos y arrastrarse por el suelo (II, XLI)

[viendo la pelea de don Quijote y al cabrero] Reventaban de risa el canónigo y el cura, saltaban los cuadrilleros de gozo, zuzaban los unos y los otros, como hacen a los perros cuando en pendencia están trabados (II, LII).

\section{Segunda Parte}

[don Quijote] desperezándose, bien como si de algún grave y profundo sueño despertara (II, XXII)

el venerable Montesinos, se puso de rodillas ante el lastimado caballero [Durandarte], y, con lágrimas en los ojos, le dijo:/ —Ya, señor Durandarte, carísimo primo mío, ya hice lo que mandaste [...]» (II, XXIII)

miren cómo [el moro a Melisendra, en el retablo de maese Pedro] le da un beso en mitad de los labios, y la priesa que ella se da a escupir (II, XXVI)

[don Quijote y Sancho] más mojados que muertos de sed, Sancho, puesto de rodillas, las manos juntas y los ojos clavados al cielo (II, XXIX)

Fue Sancho [a pedirle perdón a don Quijote] y pidió la mano a su señor, y él se la dio con reposado continente; y después que se la hubo besado, le echó la bendición (II, XXX)

en pie don Quijote, temblando de los pies a la cabeza como azogado, con presurosa y turbada lengua dijo:/ $-\mathrm{El}$ lugar donde estoy, y la presencia ante quien me hallo [...] (II, XXXII) 
Esto dicho [los cuatro salvajes], dejando a Clavileño, con gentil continente se volvieron por donde habían venido (II, XLI)

[don Quijote] con gran prosopopeya y contoneo salió a la antesala, donde el duque y la duquesa estaban (II, XLVI)

[doña Rodríguez, con] una media vela encendida [...]. Venía pisando quedito, y movía los pies blandamente (II, XLVIII)

llenas de cólera y deseosas de venganza, entraron de golpe en el aposento (II, L)

saltando, corriendo y brincando, llegó al pueblo la muchacha (II, L)

Y con gran furia y muestras de enojo [don Quijote], se levantó de la silla (II, LVIII)

doña Guiomar de Quiñones se quiso arrojar del coche para besar los pies y las manos del duque (II, LX)

Apretóle la mano Claudia [a don Vicente], y apretósole a ella el corazón, de manera que sobre la sangre y pecho de don Vicente se quedó desmayada (II, LX)

Don Quijote quedó suspenso y atónito [...] y con reposo y ademán severo le respondió [al Caballero de la Blanca Luna] (II, LXIV)

dio el sol con sus rayos en los ojos a Sancho, despertó, y esperezóse, sacudiéndose y estirándose los perezosos miembros (II, LXVIII)

Don Quijote, que le vio [a Sancho] ir con denuedo y con brío [a azotarse], le dijo: [...] (II, LXXI)

subieron una cuesta arriba, desde la cual descubrieron su aldea, la cual, vista de Sancho, se hincó de rodillas, y dijo:/ - Abre los ojos, deseada patria, y mira que vuelve a ti Sancho Panza tu hijo [...] (II, LXXII).

Autoadaptadores

\section{Primera Parte}

Estábase [Sancho] mirando las locuras que su amo hacía, y arrancábase las barbas, maldiciendo la hora y el punto en que la fortuna se le había dado a conocer (I, XVIII) 
le pareció [a Sancho] que no podía mudarse sin hacer estrépito y ruido, y comenzó a apretar los dientes y a encoger los hombros, recogiendo en sí el aliento todo cuanto podía (I, XX)

apenas hubieron llegado [los vapores de Sancho cuando se mudó] cuando él [don Quijote] fue al socorro, apretándolas [sus narices] entre los dos dedos, y con tono algo gangoso, dijo:/ -Paréceme, Sancho, que tienes mucho miedo (I, XX)

Cuando Sancho vio que no hallaba el libro, fuésele parando mortal el rostro; y tornándose a tentar todo el cuerpo muy apriesa, tornó a echar de ver que no le hallaba y, sin más ni más, se echó entrambos puños a las barbas, y se arrancó la mitad de ellas, y luego, apriesa y sin cesar, se dio media docena de puñadas en el rostro y en las narices, que se las bañó todas en sangre (I, XXVI)

Paróse Sancho Panza a rascar la cabeza, para traer a la memoria la carta, y ya se ponía sobre un pie, y ya sobre otro; unas veces miraba al suelo, otras al cielo, y al cabo de haberse roído la mitad de la yema de un dedo, teniendo suspensos a los que esperaban que ya la dijese [la carta], dijo al cabo de grandísimo rato: [...] (I, XXVI)

Decía esto Sancho con tanto reposo, limpiándose de cuando en cuando las narices, $y$ con tan poco juicio (I, XXVI)

la hermosa moza [Dorotea] alzó la cabeza y apartándose los cabellos de delante de los ojos con entrambas manos, miró los que el ruido hacían (I, XXVIII)

la hermosa moza alzó la cabeza y apartándose los cabellos de delante de los ojos con entrambas manos (I, XXVIII)

Cuando su hija lo vio se cubrió los ojos por no verle (I, XLI)

y cuando, por habernos hecho a la vela, no podimos oír sus palabras [el padre de la mora], vimos sus obras, que eran arrancarse las barbas, mesarse los cabellos y arrastrarse por el suelo (I, XLI)

Y por no oílle [Clara], se tapó con las manos entrambos oídos (I, XLIII)

Limpióse el mozo los soñolientos ojos y miró de espacio al que le tenía asido (I, XLIV). 


\section{Segunda Parte}

Las maldiciones que las dos, ama y sobrina [...] mesaron sus cabellos, arañaron sus rostros, y al modo de las endechaderas [plañideras de alquiler] que se usaban, lamentaban la partida como si fuera la muerte de su señor (II, VII)

[recuerda bien] cómo te recibe: [...] si levanta la mano al cabello para componerle, aunque no este desordenado [...] porque si tú me los relatares como ellos fueron, sacaré yo lo que ella tiene escondido en lo secreto de su corazón (II, X)

Despabilé los ojos, limpiémelos, y vi que no dormía, sino que realmente estaba despierto (II, XXIII)

miren cómo [el moro a Melisendra, en el retablo de maese Pedro] le da un beso en mitad de los labios, y la priesa que ella se da a escupir, y a limpiárselos con la blanca manga de su camisa, y cómo se lamenta, y se arranca de pesar sus hermosos cabellos (II, XXVI)

Y [el Caballero de la Barba Blanca] tosió luego y manoseóse la barba de arriba abajo con entrambas manos, y con mucho sosiego estuvo atendiendo la respuesta del duque (II, XXXVI)

[doña Rodríguez] entre los dedos de la mano izquierda traía una media vela encendida, y con la derecha se hacía sombra, porque no le diese la luz en los ojos (II, XLVIII)

[Claudia, al morir su esposo] rompió los aires con suspiros, hirió los cielos con quejas, maltrató sus cabellos, entregándolos al viento, afeó su rostro con sus propias manos (II, LX)

[Claudia, al morir su esposo] maltrató sus cabellos, afeó su rostro con sus propias manos (II, LX)

Y levantándose [Sancho] después de haberse sacudido el sayo y las migajas de las barbas [..] (II, LXVI)

Hizo Altisidora muestras de limpiarse las lágrimas con un pañuelo (II, LXX).

\section{Alteradaptadores}

\section{Primera Parte}

[don Quijote] llamó al ventero y [...] se hincó de rodillas ante él, diciéndole:/ —No me levantaré jamás de donde estoy, valeroso caballero, fasta que [no me arme caballero] (I, III) 
[el ventero, armando caballero a don Quijote] al cual mandó hincar de rodillas; $y$, leyendo en su manual -como que decía alguna devota oración-, en mitad de la leyenda alzó la mano y dióle sobre el cuello un buen golpe, y tras él, con su mesma espada, un gentil espaldarazo, siempre murmurando entre dientes (I, III)

[don Quijote] ensillando luego a Rocinante, subió en él, y abrazando a su huésped, le dijo cosas tan extrañas (I, III)

Y en diciendo esto, picó a su Rocinante [I, IV)

A estas voces salieron todos, y [...] corrieron a abrazarle [a don Quijote] $(I, V)$

[Sancho] llego a tenerle el estribo, y antes que subiese se hincó de rodillas delante dél, y asiéndole de la mano, se la besó (I, X)

y besándole [Sancho a don Quijote] otra vez la mano y la falda de la loriga, le ayudó a subir sobre Rocinante (I, X)

[don Quijote] sentándose en el lecho como pudo, tomando la mano a la ventera, le dijo:/ - Creedme , fermosa señora [...] (I, XVI)

[don Quijote, agarrando a la criada de la venta en la oscuridad] Y, teniéndola bien asida, con voz amorosa y baja le comenzó a decir:-l Quisiera hallarme en términos, fermosa y alta señora, de poder pagar tamaña merced como la que con la vista dé vuestra gran fermosura me habedes hecho [...] (I, XVI)

la asturiana, la cual, en camisa y descalza [...], con tácitos y atentados pasos, entró en el aposento (I, XVI)

$\mathrm{Y}$ allí, puesto Sancho en mitad de la manta, comenzaron a levantarle en alto, y a holgarse con él (I, XVII)

Y diciendo esto [don Quijote], puso las espuelas a Rocinante, y, puesta la lanza en el ristre [...] (I, XVIII)

le enristró [al barbero] con el lanzón bajo, llevando intención de pasarle de parte a parte (I, XXI)

¡Salgan [...] a recebir a la flor de la caballería [...]! [...] y él [el rey] llegará hasta la mitad de la escalera, y le abrazará estrechísimamente, y le dará paz, besándole en el rostro, y luego le llevará por la mano al aposento de la señora reina (I, XXI)

y el caballero le besará [al rey] cortésmente las manos por la merced que le face (I, XXI) 
La infanta volverá en sí, y dará sus blancas manos por la reja al caballero, el cual las besará mil y mil veces y se las bañará en lágrimas (I, XXI)

Besóle las manos Sancho [a don Quijote cuando le dio el dinero encontrado] por la merced (I, XXIII)

[Don Quijote al mancebo] apeándose de rocinante, con gentil continente y donaire, le fue a abrazar, y le tuvo un buen espacio estrechamente entre sus brazos, como si de luengos tiempos le hubiera conocido [...] El otro [...] le apartó un poco de sí, y, puestas sus manos en los hombros de don Quijote, le estuvo mirando, como que quería ver si le conocía (I, XXIII)

y fue al fin de las réplicas asirse [Sancho y el cabrero] de las barbas y darse tales puñadas que [...] se hicieran pedazos (I, XXIV)

a lo que más se estendía mi desenvoltura era a tomarle, casi por fuerza, una de sus bellas y blancas manos, y llegarla a mi boca, según daba lugar la estrechez de una baja reja que nos dividía [a Cardenio y Luscinda] (I, XXVII)

ella no respondía palabra, atónita y confusa. Llegaron, pues, a ella, y asiéndola por la mano el cura, prosiguió diciendo: [...] (I, XXVIII)

[Dorotea] en llegando junto a él [don Quijote], el escudero se arrojó de la mula y fue a tomar en los brazos a Dorotea (I, XXVIII)

[Dorotea] Calló en diciendo esto, y el rostro se le cubrió de un color que mostró bien claro el sentimiento y vergüenza del alma (I, XXIX)

Con lo que Cardenio dijo se acabó de admirar Dorotea, y, por no saber qué gracias volver a tan grandes ofrecimientos, quiso tomarle los pies para besárselos; más no lo consintió Cardenio (I, XXIX)

el escudero se arrojó de la mula y fue a tomar en los brazos a Dorotea [que estaba sobre la mula] (I, XXIX)

[Dorotea] apeándose con grande desenvoltura, se fue a hincar de rodillas ante las de don Quijote, y aunque él pugnaba por levantarla, ella, sin levantarse, le fabló en esta guisa:/ - [...] ¡oh valeroso y esforzado caballero! (I, XXIX)

[Dorotea] pugnó con mucha porfía por besarle las manos (I, XXIX)

[cuando Dorotea trata de besarle las manos] don Quijote, que en todo era comedido y cortés caballero, jamás lo consintió; antes la hizo levantar y la abrazó con mucha cortesía y comedimiento (I, XXIX) 
Estaba el barbero aún de rodillas, teniendo gran cuenta de disimular la risa (I, XXIX)

el cura [...] se fue a él [don Quijote] con los brazos abiertos y diciendo a voces: Para bien se hallado el espejo de la caballeria (I, XXIX)

[el cura] tenía abrazado por la rodilla de la pierna izquierda a don Quijote [sobre el caballo] (I, XXIX)

[Sancho] fue a tomar las riendas de la mula de Dorotea, y haciéndola detener, se hincó de rodillas ante ella, suplicándole le diese las manos para besárselas, en señal que la recibía por su reina y señora (I, $\mathrm{XXX)}$

-No haya más - dijo Dorotea - : corred, Sancho, y besad la mano a vuestros señor y pedidle perdón [...] Fue Sancho cabizbajo y pidió la mano a su señor, y él se la dio con reposado continente; y después que se la hubo besado, le echó la bendición (I, XXX)

[Andrés, reconociéndole] arremetió a don Quijote y, abrazándole por las piernas, comenzó a llorar (I, XXXI)

Reconociéndole [Andrés a] don Quijote, y asiéndole por la mano (I, XXXI)

Abrazóle Anselmo [a Lotario] tierna y amorosamente (I, XXXIII)

[Camila] con una increíble fuerza y ligereza arremetió a Lotario con la daga desenvainada (I, XXXIV)

[Anselmo y Lotario] abrazáronse los dos, y el uno preguntó por las nuevas de su vida o de su muerte [de Camila] (I, XXXIV)

[don Quijote] creyendo que ya había acabado la aventura, y que se hallaba delante de la princesa Micomicoma, se hincó de rodillas delante del cura, diciendo:/ - Bien puede vuestra grandeza, alta y famosa señoría [...](I, XXXV)

[Luscinda] le echó los brazos al cuello y juntando su rostro con el de Cardenio, le dijo:/ — Vos sí, señor mío, sois el verdadero dueño desta vuestra captiva (I, XXXVI)

Dorotea [creyendo que don Fernando iba a agredir a Cardenio] se abrazó con él por las rodillas, besándoselas y teniéndole apretado (I, XXXVI)

la señal que dio [don Fernando] de haberse rendido y entregado al buen parecer que se le había propuesto fue abajarse y abrazar a 
Dorotea, diciendo:/ - Levantaos, señora mía, que no es justo que esté arrodillada a mis pies la que yo tengo en mi alma (I, XXXVI

[Dorotea] se levantó y se fue a hincar de rodillas a sus pies [don Fernando], y derramando mucha cantidad de hermosas y lastimeras lágrimas (I, XXXVI)

Y diciendo esto [don Fernando a Dorotea], la tornó a abrazar y a juntar su rostro con el suyo (I, XXXVI)

Cardenio y Luscinda se fueron a poner de rodillas ante don Fernando, dándole gracias de la merced que les había hecho (I, XXXVI)

don Fernando [cuando Cardenio y Luscinda están de rodillas ante él] los levantó y abrazó con muestras de mucho amor y de mucha cortesía (I, XXXVI)

y de un revés, ¡zas!, le derribé [don Quijote al gigante] la cabeza en el suelo (I, XXXVII)

llegándose [el hombre que la acompañaba] a la que en el traje parecía mora, la apeó [del jumento] en sus brazos (I, XXXVII)

Dorotea la tomó por la mano [a la mora] y la llevó a sentar junto a sí (I, XXXVII)

Abrazóla Luscinda [a la mora] con mucho amor (I, XXXVII)

mi padre [el del cautivo] nos abrazó a todos (I, XXXIX)

Luego que la vi [Zoraida], le tomé una mano y la comencé a besar (I, XLI)

Él, como vio allí a su hija [Zoraida], comenzó a suspirar tiernisimamente, y más cuando vio que yo estrechamente la tenía abrazada (I, XLI)

viéndole llorar [Zoraida], así se enterneció, que se levantó de mis pies y fue a abrazar a su padre, y juntando su rostro con el suyo, comenzaron los dos tan tierno llanto (I, XLI)

el jinete se arrojó del caballo y vino a abrazar al mozo, diciéndole;/ -Sobrino de mi alma (I, XLI)

el cura [...] entrando donde estaba Zoraida, la tomó por la mano [y][...] tomándole a él [el capitán] asimesmo de la otra mano, con entrambos se fue donde el oidor y los demás caballeros estaban (I, XLII) 
Acudió el capitán a abrazar a su hermano, y él le puso ambas manos en los pechos por mirarle algo más apartado; más, cuando le acabó de conocer, le abrazó estrechamente (I, XLII)

allí abrazó el oidor a Zoraida; allí hizo que la abrazase su hija (I, XLII)

[Clara, oyendo los versos que alguien cantaba] le tomó un temblor tan estraño [...] y abrazándose estrechamente con Dorotea, le dijo:/ ¡Ay señora de mi alma y de mi vida! (I, XLIII)

Clara, temerosa de que Luscinda no la oyese, abrazando estrechamente a Dorotea, puso su boca tan junto del oído de Dorotea, que seguramente podía hablar sin ser de otro sentido (I, XLIII)

El hombre le trabó del brazo y le dijo:/ —Por cierto, señor don Luis, que [..] (I, XLIV)

Miróle entonces el oidor más atentamente y conocióle; y abrazándole, dijo: [...] (I, XLIV)

El oidor [..] tomando por la mano a don Luis, la apartó a una parte y le preguntó qué venida había sido aquélla (I, XLIV)

Y sin decir más [don Quijote] se fue a poner de hinojos ante Dorotea, pidiéndole con palabras dantescas y caballarescas que [...][ (I, XLIV)

el mozo, asiéndole fuertemente de las manos, como en señal de que algún gran dolor le apretaba el corazón, y derramando lágrimas en grande abundancia, le dijo:/ - Señor mío, yo no sé deciros otra cosa sino que [quiero casarme con vuestra hija] (I, XLIV)

Besóle las manos por fuerza don Luis [al oidor] y aún se las bañó en lágrimas (I, XLIV)

[un cuadrillero] poniéndosele a leer de espacio [un pergamino que hablaba de don Quijote], porque no era buen lector, a cada palabra que leía ponía los ojos en don Quijote (I, XLV)

[el cuadrillero] en la izquierda tomó el mandamiento, y con la derecha asió a don Quijote del cuello fuertemente, que no le dejaba alentar, y a grandes voces decía:/ — ¡Favor a la Santa Hermandad! (I, XLV)

[don Quijote, mientras el cuadrillero le tenía cogido del cuello] viéndose tratar mal de aquel villano [...] asió al cuadrillero con entrambas manos de la garganta (I, XLV) 
don Quijote] se fue a poner de hinojos ante Dorotea (I, XLVI)

Todos se abrazaron y quedaron de darse noticia de sus sucesos (I, XLVII)

Tornaron a abrazarse otra vez (I, XLVII)

[don Quijote, al salir de la jaula] se fue donde estaba Rocinante, y dándole dos palmadas en las ancas, dijo:/ - Aún espero en Dios y en su bendita Madre, flor y espejo de los caballos, que presto nos hemos de ver los dos cual deseamos (I, XLIX) L)

mí, Manchada, que tiempo nos queda para volver a nuestro apero (I,

$\mathrm{Y}$ en diciendo esto, apretó los muslos a Rocinante, porque espuelas no las tenía (I, LII)

Sancho no hizo otra cosa que arrojarse sobre el cuerpo de su señor, haciendo sobre él el más doloroso y risueño llanto del mundo, creyendo que estaba muerto (I, LII).

\section{Segunda Parte}

El cabrero dio dos palmadas sobre el lomo a la cabra, que por los cuernos tenía, diciéndole:/ -Recuéstate junto a nuestro licenciado, volviéndose a nuestro capellán y asiéndole de las manos, le dijo: (II, I)

[el bachiller Sansón ante don Quijote] poniéndose delante dél de rodillas, diciéndole:/ —Déme vuestra grandeza las manos, señor don Quijote de la Mancha (II, III)

Abrióle la sobrina [a Sancho], salió a recebirle con los brazos abiertos su señor don Quijote (II, VII)

Llegó Sansón, socarrón famoso, y abrazándole [a don Quijote] como la vez primera, y con voz levantada le dijo:/ — ¡Oh flor de la andante caballería! (II, VII)

Finalmente don Quijote y Sancho se abrazaron y quedaron amigos (II, VII)

Abrazóle Sansón [despidiéndose él y don Quijote] (II, VII) 
[don Quijote] tuvo del cabestro el jumento de una de las tres labradoras, y hincando ambas rodillas en el suelo, dijo:/ - Reina y princesa y duquesa de la hermosura [...] (II, X)

se había puesto don Quijote de hinojos junto a Sancho [ante la labradora] (II, X)

[la aldeana] tomó una corridica, y puestas ambas manos sobre las ancas de la pollina [se subió a la pollina] (II, X)

El escudero del Bosque asió por el brazo a Sancho, diciéndole:/ Vámonos los dos donde podamos hablar escuderilmente (II, XII)

El escudero del Bosque, asió por el brazo a Sancho, diciendo:/ Vámonos los dos donde podamos hablar escuderilmente (II, XII)

Sancho [...] se arrojó del rucio, y con gran priesa le fue a asir [un hidalgo] del estribo derecho, y con devoto corazón y casi lágrimas le besó los pies una y muchas veces (II, XVI)

Sancho, oyéndose llamar [...], a toda priesa picó al rucio (II, XVI)

besó las manos el leonero a don Quijote por la merced recebida (II, XVII)

se levantó en pie don Quijote, y en voz levantada, que parecía grito, asiendo con su mano la derecha de don Lorenzo, dijo:/ - iViven los cielos donde más altos están, mancebo generoso [..]! (II, XVIII)

Y levantándose [Corchuelo], abrazó al licenciado, y quedaron más amigos que de antes(II, XIX)

Quiteria, toda honesta y toda vergonzosa, asiendo con su derecha mano la de Basilio, le dijo: (II, XXI)

asidos de las manos Basilio y Quiteria, el cura, tierno y lloroso, les echó la bendición (II, XXI)

Y luego [don Quijote] se hincó de rodillas y hizo una oración en voz baja al cielo (II, XXII)

Sancho, puesto de rodillas, las manos juntas y los ojos clavados al cielo, pidió a Dios [...] (II, XXIX)

[Sancho] llegó donde la bella cazadora estaba; y apeándose, puesto de hinojos ante ella, le dijo:/ — Hermosa señora [...] (II, XXX)

Don Quijote se gallardeó en la silla, púsose bien en los estribos, acomodóse la visera, arremetió a Rocinante y con gentil denuedo fue a besar las manos a la duquesa (II, XXX) 
[don Quijote] renqueando y como pudo, fue a hincar las rodillas ante los dos señores (II, XXX)

[el duque] apeándose de su caballo, fue a abrazar a don Quijote (II, XXX)

Sancho [...] se fue a hincar de rodillas ante la duquesa (II, XXXII)

Llegó [Trifaldínl de la barba Blanca], pues, con el espacio y prosopopeya referida a hincarse de rodillas ante el duque (II, XXXVI)

Oyendo lo cual [al duque] Trifaldín, inclinó la rodilla hasta el suelo (II, XXXVI)

Ella [la dolorida], puesta de rodillas en el suelo, con voz antes basta y ronca que sutil y dilicada, dijo: [...] (II, XXXVIII)

Llegóse a mí [Montesinos a don Quijote], y lo primero que hizo fue abrazarme estrechamente (II, XXIII)

se fue maese Pedro a poner de rodillas ante don Quijote, y abrazándole las piernas, dijo:/ —Estas piernas abrazo, así como si abrazara las dos columnas de Hércules (II, XXV)

Pues miren cómo [el moro a Melisendra] le da un beso en mitad de los labios (II, XXVI)

[en las marionetas de Maese Pedro] aquel moro [...] le da un beso en mitad de los labios [a Melisendra], y la priesa que ella se da a escupir, y a limpiársela con la blanca manga de su camisa, y cómo se lamenta, y se arranca de pesar sus hermosos cabellos (II, XXVI)

[cuando don Quijote va a apearla] no quiso descender o bajar del palafrén sino en brazos del duque (II, XXX)

haciéndole [a don Quijote las cuatro doncellas] una grande y profunda inclinación y reverencia [...] haciendo reverencias se fueron (II, XXXII)

-Híncate de rodillas, Sancho - dijo don Quijote-, y besa los pies a su Excelencia por la merced que te ha hecho./ Hízolo así Sancho (II, XXXII)

De nuevo le besó las manos Sancho a la duquesa (II, XXXIII)

don Quijote se colgó del cuello de Sancho, dándole mil besos en la frente y en las mejillas (II, XXXV)

yendo [...] a besarle [a una dama] las manos, y a recebir su bendición, beneplácito y licencia para esta tercera salida (II, XXXII) 
Y levantándola de la mano [el duque a la Dolorida], la llevó a asentar en una silla junto a la duquesa, la cual la recibió asimismo con mucho comedimiento (II, XXXVIII)

La Dolorida dueña hizo señal de querer arrojarse a los pies de don Quijote, y aun se arrojó, y pugnando por abrazárselos, decía/ - Antes estos pies y piernas me arrojo, ;oh caballero invicto!, por ser los que son basas y colunas de la andante caballería (II, XXXVIII)

[la dolorida] se volvió a Sancho Panza y asiéndole de las manos, le dijo:/ — ¡Oh tú, el más leal escudero [...]! (II, XXXVIII)

[don Quijote] apartando a Sancho entre unos árboles del jardín y asiéndole ambas las manos le dijo: (II, XLI)

[don Quijote] le tomó por la mano [a Sancho] y se fue con el a su estancia, con intención de aconsejarle (II, XLII)

Oyó Sancho las voces, y apretándose con su amo y ciñiéndole con los brazos, le dijo: (II, XLI)

Leyó el duque el cartel con los ojos medio cerrados, y luego, con los brazos abiertos, fue a abrazar a don Quijote (II, XLI)

Al despedirse de los duques [Sancho], les besó las manos, y tomó la bendición de su señor, que se la dio con lágrimas, y Sancho la recibió con pucheritos (II, XLIV)

Y poniéndose de rodillas [el labrador], le pidió la mano para besársela (II, XLVII)

Y diciendo esto [don Quijote], besó su derecha mano [de doña Rodríguez], y le asió de la suya, que ella le dio con las mismas ceremonias (II, XLVIII

[una mujer] llegándose a don Quijote, se le echó a los pies tendida de largo a largo, la boca cosida con los pies de don Quijote, y daba unos gemidos tan tristes, y tan profundos, y tan dolorosos (II, LII)

Abrazáronle todos y él [Sancho], llorando, abrazó a todos (II, LIII)

De cuando en cuando juntaba alguno [de los peregrinos] su mano derecha con la de Sancho, y decía:/ —Español y tudesqui, tuto uno: bon compaño (II, LIV)

y picando al rucio [Sancho] rompió por ellos (II, LIV) 
uno de ellos [...] arremetió a él, echándole los brazos por la cintura, y en voz alta y muy castellana, dijo:/ - [...] ¿Es posible [...] mi buen vecino Sancho Panza? (II, LIV)

Sancho [...] le vino a conocer de todo punto, y sin apenas apearse del jumento, le echó los brazos al cuello (II, LIV)

Y luego se abrazaron los dos, y Sancho subió a su rucio y Ricote se arrimó a su bordón, y se apartaron (II, LIV)

y luego [Sancho] subió a ver a sus señores, ante los cuales, puesto de rodillas, dijo:/ - Yo, señores, porque lo quiso así vuestra grandeza, sin ningún merecimiento mío, fui a gobernar vuestra ínsula Barataria (II, LV)

y el duque abrazó a Sancho, y le dijo que le pesaba en el alma de que hubiese dejado tan presto el gobierno (II, LV)

Abajó la cabeza don Quijote y hizo reverencia a los duques y a todos los circunstantes (II, LVII)

Sancho Panza [..] arremetiendo a su amo, se abrazó a él a brazo partido, y echándole una zancadilla, dio con él en el suelo boca arriba; púsole la rodilla derecha sobre el pecho, y con las manos le tenía las manos, de modo que ni le dejaba rodear ni alentar (II, LX)

Claudia se turbó en ver la [presencia] de don Vicente; así, entre enternecida y rigurosa, se llegó a él, y asiéndole de las manos, le dijo: (II, LX)

No lo dijo tan paso [ofendiendo a Roque] el desventurado, que dejase de oirlo Roque, el cual, echando mano a la espada, le abrió la cabeza casi en dos partes(II, LX)

Llegaron [Roque y don Quijote] a su playa la víspera de San Juan en la noche, y abrazando Roque a don Quijote y a Sancho (II, LXI)

En esto, tomándole la mano don Antonio [a don Quijote], se la paseó por la cabeza de bronce y por toda la mesa, y por el pie de jaspe sobre que se sostenía (II, LXII)

Diole la mano el general, que con este nombre le llamaremos, que era un principal caballero valenciano; abrazó a don Quijote (II, LXIII)

Hizo señal el cómitre que zarpasen el ferro [subiesen el áncora] (II, LXIII)

un anciano [...] apenas dio fin a su plática la morisca, cuando él se arrojó a sus pies, y abrazado dellos, con interrumpidas palabras de mil 
sollozos y suspiros, le dijo:/- ¡Oh Ana Félix, desdichada hija mía! (II, LXIII)

aquélla era su hija [Ana Félix], la cual, ya desatada, a abrazó a su padre, mezclando sus lágrimas con las suyas (II, LXIII)

[Tosilos] abrazándole [a don Quijote] por el muslo derecho, que no alcanzaba más, le dijo, con muestras de mucha alegría:/ — ¡Oh, mi señor don Quijote de la mancha [...]! (II, LXVI)

Llegaron, en esto, los de a caballo, y arbolando las lanzas [...] rodearon a don Quijote y se las pusieron a las espaldas y pechos, amenazándole de muerte (II, LXVIII)

Al subir el duque y la duquesa en el teatro se levantaron don Quijote y Sancho y les hicieron una profunda humillación, y los duques hicieron lo mesmo, inclinando algún tanto la cabeza (II, LXIX)

Sancho [...] dio rostro y barba a la primera [dueña], la cual la hizo una mamona muy bien sellada, y luego una gran reverencia (II, LXIX) ${ }^{17}$

Altisidora [...] mirando de través a don Quijote, le dijo:/ -Dios te lo perdone, desamorado caballero (II, LXIX)

Besóle por ello las manos Sancho [a Altisidora], con la coroza en la mano y la rodilla en el suelo (II, LXIX)

entró el músico, cantor y poeta [...], el cual, haciendo una gran reverencia a don Quijote, dijo:/ - Vuestra merced, señor caballero, me cuente y tenga en el número de sus servidores (II, LXX)

y haciendo [Altisidora] reverencia a sus señores, se salió del aposento (II, LXX)

[el cura y el bachiller] se vinieron a ellos con los brazos abiertos (II, LXXIII)

Apeóse don Quijote y abrazólos estrechamente [al cura y al bachiller] (II, LXXIII)

Abrazó Sanchica a su padre y preguntóle si traía algo (II, LXXIII)

y asiéndole [a Sancho, su hija] de un lado del cinto, y su mujer de la mano [...] se fueron a su casa (II, LXXIII)

17 «Burla que se hacía poniendo a uno los cinco dedos de la mano derecha sobre la cara y, levantando el medio con el índice de la izquierda, se soltaba rápidamente disparándolo contra la nariz» (Don Quijote, ed. de Martín de Riquer, 1965: 748). 
Tomóle el pulso [el médico a don Quijote], y no le contentó mucho (II, LXXIV).

Somatoadaptadores

\section{Primera Parte}

[don Quijote] con gentil continente y denuedo, se afirmó bien en los estribos, apretó la lanza, llegó la adarga al pecho (I, IV)

[don Quijote] cubierto de su rodela, con la lanza en el ristre, arremetió a todo galope de Rocinante y embistió con el primer molino (I, VIII)

[Sancho] sobre su jumento [...] iba caminando y comiendo [...] muy de su espacio, y de cuando en cuando empinaba la bota (I, VIII)

mucho mejor me sabe lo que me como en mi rincón sin melindres ni respetos, aunque sea pan y cebolla, que los gallipavos de otras mesas donde me sea forzoso mascar despacio, beber poco, limpiarme a menudo, no estornudar ni toser si me viene en gana (I, XI)

[don Quijote y Sancho con los cabreros] con mucho donaire y gana, embaulaban tasajo como el puño (I, XI)

Y esto dijo afirmándose en los estribos y calándose el morrión (I, $\mathrm{XXX)}$

cuando [Lotario] le vio caminar, embozarse y encubrirse con cuidado y recato (I, XXXIV)

Oyendo esto [que llegaban huéspedes a la venta] Dorotea, se cubrió el rostro (I, XXXVI).

\section{Segunda Parte}

Comió Sancho sin hacerse de rogar, y tragaba a escuras bocados de nudos de suelta [muy grandes] (II, XIII) 
enseñóle el caldero lleno de gansos y de gallinas, y [Sancho] asiendo de una, comenzó a comer con mucho donaire y gana (II, XX)

Ten cuenta, Sancho, de no mascar a dos carrillos ni de erutar delante de nadie (II, XLIII)

¡Miserable del bien nacido que va dando pistos a su honra, comiendo mal y a puerta cerrada, haciendo hipócrita el palillo de dientes con que sale a la calle después de no haber comido cosa que le obligue a limpiárselos! (II, XLIV)

Don Quijote [...] colgó el tahelí de sus hombros con su [...] espada, asió un gran rosario que consigo continuo tenía, y con gran prosopopeya y contoneo salió a la antesala, donde el duque y la duquesa estaban (II, XLVI)

Y luego [don Quijote], descalzándose un guante, le arrojo en mitad de la sala [en desafío] (II, LII)

Comenzaron a comer [Sancho y los peregrinos] con grandísimo gusto y muy de espacio, saboreándose con cada bocado, que le tomaban con la punta del cuchillo, y muy poquito de cada cosa, y luego al punto, todos a una, levantaron los brazos y las botas en el aire; puestas las bocas en su boca, clavados los ojos en el cielo, no parecía sino que ponían en él la puntería; y desta manera, meneando las cabezas a un lado y a otro, señales que acreditaban el gusto que recebían, se estuvieron un buen rato (II, LIV)

Sancho [...] comenzó a embaular en el estómago el pan y queso que se le ofrecía (II, LIX)

con cuatro dedos de muñecas de fuera [de las mangas], para hacer las manos más largas, como ahora se usa (II, LXIX).

Objetoadaptadores

Primera Parte

[el ventero, armando caballero a don Quijote, le dio] con su mesma espada, un gentil espaldarazo (I, III) 
[don Quijote] embrazó su adarga y, puesta mano a su espada, dijo:/ - iOh señora de la fermosura, esfuerzo y vigor del debilitado corazón mío! (I, III)

y, embrazando su adarga, asió de su lanza, y con gentil continente se comenzó a pasear delante de la pila (I, III)

[don Quijote] arrimado a su lanza, ponía los ojos en las armas, sin quitarlos por un buen espacio dellas (I, III)

[el ventero, armando caballero a don Quijote] al cual mandó hincar de rodillas; $y$, leyendo en su manual —como que decía alguna devota oración-, en mitad de la leyenda alzó la mano y dióle sobre el cuello un buen golpe, y tras él, con su mesma espada, un gentil espaldarazo, siempre murmurando entre dientes (I, III)

El labrador, que vio sobre si aquella figura llena de armas blandiendo la lanza sobre su rostro (I, IV)

apretó la lanza, llegó la adarga al pecho y, puesto en la mitad del camino [...] levanto don Quijote la voz y con ademán arrogante dijo: / Todo el mundo se tenga, si todo el mundo no confiesa que no hay en el mundo doncella más hermosa que [...] Dulcinea del Toboso (I, IV)

[don Quijote] arremetió con la lanza baja contra el que lo había dicho (I, IV)

[Sancho] iba caminando y comiendo detrás de su amo muy de su espacio, y de cuando en cuando empinaba la bota, con tanto gusto que le pudiera envidiar el más regalado bodegonero de Málaga (I, VIII)

[don Quijote] la lanza baja, arremetió contra el primer fraile (I, VIII)

El decir esto, y el apretar la espada, y el cubrirse bien de su rodela, y el arremeter al vizcaíno, todo fue en un tiempo (I, VIII)

Y sin esperar más respuesta, picó a rocinante y, la lanza baja, arremetió contra el primer fraile (I, VIII)

Dejamos en la primera parte de esta historia al valeroso vizcaíno y al famoso don Quijote con las espadas altas y desnudas, en guisa de descargar dos furibundos fendientes [golpes verticales] (I, IX)

pintada muy al natural la batalla de don Quijote con el vizcaíno, puestas en la misma postura que la historia cuenta, levantadas las espadas (I, IX)

[Sancho] llego a tenerle el estribo, y antes que subiese se hincó de rodillas delante dél, y asiéndole de la mano, se la besó y le dijo:/ —Sea 
vuestra merced servido, señor don Quijote mío, de darme el gobierno de la ínsula que en esta rigurosa pendencia se ha ganado (I, X)

puesta la mano en la espada y alzando los ojos al cielo [don Quijote], dijo:/ - Yo hago juramento al Criador de todas las cosas (I, $\mathrm{X})$

$\mathrm{Y}$ diciendo esto [don Quijote], puso las espuelas a Rocinante, $y$, puesta la lanza en el ristre [...] (I, XVIII)

Figurósele que la litera eran andas donde debía de ir algún malferido o muerto caballero [...] enristró su lanzón, púsose bien en la silla, y con gentil brío y continente se puso en la mitad del camino (I, XIX)

Y esto dijo [don Quijote] afirmándose en los estribos y calándose el morrión (I, XXX)

[don Quijote, preguntando sobre la carta que dio a Sancho para Dulcinea] cuando le diste mi carta, ¿besóla? ¿Púsosela sobre la cabe$z a$ ? [se hacía con carta de persona muy importante, por respeto] (I, $\mathrm{XXXI)}$

subió sobre Rocinante, embrazó su adarga, enristró su lanzón, y [...] volvió a medio galope (I, XLIV)

[don Quijote] embrazando su adarga y poniendo mano a su espada (I, XLIV)

Y el decir esto y el darle con la punta del cuchillo los lomos de un conejo fiambre, todo fue uno $(\mathrm{I}, \mathrm{L})$

[don Quijote] subió sobre Rocinante y embrazó su adarga, y dijo en alta voz a todos (I, LII).

\section{Segunda Parte}

[Sancho con la bota de vino] empinándola, puesta a la boca, estuvo mirando las estrellas un cuarto de hora (II, XIII)

Y diciendo esto, se levantó en pie y se empuñó en la espada, esperando qué resolución tomaría el Caballero del Bosque (II, XIV)

don Quijote [...] afirmándose bien en los estribos, requiriendo la espada y asiendo la lanza, dijo:/ - Ahora venga lo que viniera; que 
aquí estoy con ánimo de tomarme con el mismo Satanás en persona [...] (II, XVII)

Levantados, pues, los manteles, y dadas gracias a Dios y agua a las manos [...] (II, XVIII)

[Basilio, el falso suicida en las bodas de Camacho] Llegó, en fin, cansado y sin aliento, y puesto delante de la desposada, hincando el bastón en el suelo, que tenía el cuento de una punta de acero, mudada la color, puestos los ojos en Quiteria, con voz tremente y ronca (II, $\mathrm{XXI})$

las doncellas [...] con aderezo de darle agua a las manos; la cual le dieron con muchas reverencias y ceremonias (II, XXXI)

Llegó la de la fuente, y con gentil donaire y desenvoltura encajó la fuente debajo de la barba de don Quijote (II, XXXIII)

y en viéndole [al jabalí], embrazando su escudo y puesta la mano a su espada, se adelantó a recebirle don Quijote (II, XXXIV)

Tornó a tomar su báculo el deudor [tras ser juzgado], y bajando la cabeza, se salió del juzgado (II, XLV)

levantándose en pie el gobernador [Sancho], asió de la silla en que estaba sentado, y dijo:/ - ¡Voto a tal, don patán rústico y mal mirado [...]! (II, XLVII)

[el paje] se arrojó del caballo y se fue con mucha humildad a poner de hinojos ante la señora Teresa (II, L)

Y luego [don Quijote], descalzándose un guante, le arrojó en mitad de la sala, y el duque se alzó, diciendo que [...] acetaba el tal desafío (II, LII)

Bajó el gobernador la vara [para jurar sobre ella] [...] el viejo [...] puso la mano en la cruz de la vara, diciendo que era verdad que (II, XLV)

y [don Quijote] puesto sobre Rocinante, embarazando su escudo y tomando su lanza, se puso en la mitad de un real camino (II, LVIII)

Madrugó don Quijote, y dando golpes al tabique del otro aposento, se despidió de sus huéspedes (II, LIX)

Oyólo un escudero, y enarboló el mocho [culata] de un arcabuz, con el cual sin duda le abriera la cabeza a Sancho (II, LX) 
[al oír el estruendo de lo que resultó ser una piara de cerdos] Levantóse don Quijote y puso mano a la espada (II, LXVIII)

Así como don Quijote vio rebullir a Altisidora, se fue a poner de rodillas delante de Sancho, diciéndole:/ - Ahora es tiempo, hijo de mis entrañas, no que escudero mío [...] (II, LXIX)

Besóle por ello las manos Sancho [a Altisidora], con la coroza en la mano y las rodillas en el suelo (II, LXIX).

\section{Posturas}

\section{Emblemas}

Segunda Parte

Sancho [...] con pasos quedos, el cuerpo agobiado y el dedo puesto sobre los labios, anduvo por toda la sala levantando los doseles por si les veía alguien (II, XXXIII)

venían hasta seis dueñas [...] las cuatro con antojos, y todas levantadas las manos derechas e alto, con cuatro dedos de muñecas de fuera [de la ropa], para hacer las manos más largas, como ahora se usa [II, LXIX).

\section{Exteriorizadores}

\section{Primera Parte}

El labrador [ante la amenaza de don Quijote] bajó la cabeza y, sin responder, desató a su criado (I, IV)

el vizcaíno le aguardaba ansimesmo levantada la espada y aforrado con su almohada (I, VIII)

Cuando yo oí decir «Dulcinea del Toboso», quedé atónito y suspenso (I, IX) 
cuando don Quijote llegó a ver rota su celada, pensó perder el juicio, y, puesta la mano en la espada y alzando los ojos al cielo, dijo:/ Yo hago juramento al Criador de todas las cosas (I, X)

Los que hasta entonces no la habían visto [a Marcela] la miraban con admiración y silencio (I, XIV)

[don Quijote] puesta la mano en el puño de su espada, en altas e inteligibles voces, dijo:/ -Ninguna persona [....] se atreva a seguir a la hermosa Marcela, so pena de caer en la furiosa indignación mía (I, XIV)

Figurósele que la litera eran andas donde debía de ir algún malferido o muerto caballero [...] enristró su lanzón, púsose bien en la silla, y con gentil brío y continente se puso en la mitad del camino (I, XIX)

Las demás guardas quedaron atónitas y suspensas del no esperado acontecimiento (I, XXII)

[don Quijote] si más ni más, dio dos zapatetas en el aire y dos tumbas la cabeza abajo y los pies en alto (I, XXV)

Fue Sancho cabizbajo [a pedirle perdón a don Quijote] (I, XXX)

el hombre, cuando los vio, sin sobresaltarse, estuvo quedo, con la cabeza inclinada, a guisa de hombre pensativo, sin alzar los ojos a mirarlos (I, XXVII)

Llegó el desposado [don Fernando] a abrazar a su esposa [Luscinda], y ella, poniéndose la mano sobre el corazón,cayó desmayada en los brazos de su madre (I, XXVII)

don Fernando [después de leer el papel encontrado en el pecho de Luscinda] se sentó en una silla y se puso la mano en la mejilla, con muestras de hombre muy pensativo (I, XXVII)

[don Fernando, después de leer un papel] se puso la mano en la mejilla, con muestras de hombre muy pensativo (I, XXVII)

[cuando Dorotea nombró a don Fernando] Cardenio [..] no hizo otra cosa que trasudar y estarse quedo, mirando de hito en hito a la labradora, imaginándose quién era ella (I, XXVIII)

Fue Sancho cabizbajo [a pedirle perdón a don Quijote] (I, XXX)

Andrés asió de su pan y queso y, viendo que nadie le daba otra cosa, abajó su cabeza y tomó el camino en las manos (I, XXXI) 
las doncellas de la burla tenían los ojos bajos, sin osar mirar a sus señores (II, XXXII)

Anselmo quedó tan confuso y pensativo, que por un buen espacio no le pudo responder palabra (I, XXXIII)

la honesta presencia de Camila, la gravedad de su rostro, la compostura de su persona era tanta, que ponía freno a la lengua de Lotario (I, XXXIII)

Absorto, suspenso y admirado quedó Anselmo con las razones de Lotario [...] Callando estuvo por un buen espacio, mirando al suelo sin mover pestaña, y al cabo dijo: [...] (I, XXXIV)

don Quijote, que no cabía en su asiento de puro alborotado (II, XXXVI)

al sentarse la mujer [Dorotea] en la silla dio un profundo suspiro, y dejó caer los brazos, como persona enferma y desmayada (I, XXXVI)

[don Quijote] embazó [se inmóvil y confuso] y se estuvo quedo [si socorrer al ventero] (I, XLIV)

Sancho [...] vino muy humilde, y, hincándose de rodillas, pidió la mano la mano a su amo [...] (I, XLVI)

iban el cura y el barbero sobre sus poderosas mulas, cubiertos los rostros [...] con grave y reposado continente (I, XLVII)

Hizo señas el maestresala al labrador que se saliese de la sala, el cual lo hizo cabizbajo y, al parecer, temeroso (II, XLVIII)

Replicar quería Sancho a su amo, pero la voz del Caballero del Bosque [...] lo estorbó, y estando los dos atónitos, oyeron que lo que cantó fue este soneto (II, XII)

dijo Sancho a los labradores, que estaban muchos alrededor del, la boca abierta, esperando la sentencia suya (II, LXVI)

[don Quijote] tenía la cabeza inclinada sobre el pecho, con muestras de estar corrido (I, XX)

Sancho [..] tenía los carrillos hinchados, y la boca llena de risa, con evidentes señales de querer reventar con ella [...] y [...] soltó la presa de tal manera que tuvo necesidad de apretarse las ijadas con los puños, por no reventar riendo (I, XX)

Quedó pasmado don Quijote, absorto Sancho, suspenso el primo, atónito el paje, abobado el del rebuzno, confuso el ventero (II, XXV) 
Oyó Cardenio el nombre de Luscinda, y no hizo otra cosa que encoger los hombros, morderse los labios, enarcar las cejas, y dejar de allí a poco caer por sus ojos dos fuentes de lágrimas (I, XXVIII).

\section{Segunda Parte}

Miraba Sancho a don Quijote de hito en hito, en tanto que tales vituperios le decía (II, XXVIII)

Sancho, embobado y atónito de ver la honra que a su señor aquellos príncipes le hacían (II, XXXI)

Don Quijote y Sancho [...] quedaron atónitos de verse en el mesmo jardín de donde habían partido (II, XLI)

Tornó a tomar su báculo el deudor [tras ser juzgado], y bajando la cabeza, se salió del juzgado (II, XLV)

Espantóse la mujer [tras ser juzgada por Sancho] y fuese cabizbaja y mal contenta (II, XLV)

Oyendo esto Sancho, se arrimó sobre el respaldar de la silla y miró de hito en hito al tal médico (II, XLVII)

Hizo de señas el maestresala al labrador que se saliese de la sala, el cual lo hizo cabizbajo y, al parecer, temeroso (II, XLVII)

Sancho quedó pasmado de la hermosura de la moza [la hija de Pedro Pérez Mazorca]. Ella, puestos los ojos en tierra con honestísima vergüenza, respondió:/ - No puedo, señor, decir tan en público lo que tanto me importaba fuera secreto (II, XLIX)

don Quijote [...] tuvo por bien de cruzar las manos e inclinar la cabeza [...] pensativo, con la más triste y melancólica figura que pudiera formar la misma tristeza (II, LX)

abrió los ojos Sancho, y alzó la cabeza — que inclinaba tenía, pensando en la desgracia de su paseo- (II, LXIII)

[al oír el estruendo de lo que resultó ser una piara de cerdos] Sancho se agazapó debajo del rucio, poniéndose a los lados el lío de las armas y la albarda de su jumento, tan temblando de miedo (II, LXVIII)

Altisidora [...] entró en el aposento de don Quijote; con cuya presencia turbado y confuso, se encogió y cubrió casi todo con las sába- 
nas y colchas de la cama, muda la lengua, sin que acertase a hacerle cortesía alguna (II, LXX).

Autoadaptadores

\section{Primera Parte}

Muchas veces tomé la pluma [...] y estando en suspenso, con el papel delante [...] la mano en la mejilla, pensando lo que diría (I, «Prólogo»)

se le había caído a Cardenio la cabeza sobre el pecho, dando muestras de estar profundamente pensativo (I, XXIV).

\section{Segunda Parte}

Sancho, puesto de rodillas, las manos juntas y los ojos clavados al cielo, pidió a Dios [...] (II, XXIX)

Pero lo que hizo [Lotario] fue poner el codo sobre el brazo de la silla, y la mano abierta en la mejilla, y [...] dijo que quería reposar un poco en tanto que Anselmo volvía (II, XXXIII)

[Montesinos] Tenía la mano derecha [...] puesta sobre el lado del corazón [...] me dijo: «Éste es mi amigo Durandarte, flor y espejo de los caballeros andantes enamorados [...]» (II,XXIII)

Iba Zoraida, en tanto que se navegaba, puesto la cabeza entre mis manos, por no ver a su padre (II, XLI)

Sancho [...] inclinó la cabeza sobre el pecho, y poniéndose el índice de la mano derecha sobre las cejas y las narices, estuvo como pensativo un pequeño espacio (II, XLV). 


\section{Alteradaptadores}

\section{Primera Parte}

[Zoraida] echándome un brazo al cuello, con desmayados pasos comenzó a caminar hacia la casa [y cuando les vio su padre] se llegó más a mi y puso su cabeza sobre mi pecho, doblando un poco las rodillas, dando claras señales y muestras que se desmayaba (I, XLI).

\section{Segunda Parte}

Inclinóse maese Pedro [ante don Quijote], diciéndole: (II, XXVI).

\section{Objetoadaptadores}

\section{Primera Parte}

Muchas veces tomé la pluma [...] y estando en suspenso, con el papel delante, la pluma en la oreja, el codo en el bufete y la mano en la mejilla, pensando lo que diría (I, "Prólogo')

adonde su escudero estaba, de pechos sobre su asno, con la mano en la mejilla, en guisa de hombre pensativo además (I, VIII)

puesta la mano en la espada y alzando los ojos al cielo [don Quijote], dijo:/ - Yo hago juramento al Criador de todas las cosas (I, X)

Y poniendo piernas al Rocinante, y terciando su lanzón, se salió de la venta (I, XVII)

[Sancho] iba tras su amo sentado a la mujeriega sobre su jumento (I, XXIII)

Pero lo que hizo [Lotario] fue poner el codo sobre el brazo de la silla y la mano abierta en la mejilla, y [...] dijo que quería reposar un poco (I, XXXIII) 
Parecióle a Dorotea que don Fernando había perdido la color del rostro y que hacía ademán de querer vengarse de cardenio porque le vió encaminar la mano a ponella en la espada (I, XXXVI)

don Quijote estaba a caballo, recostado sobre su lanzón, dando de cuando en cuando tan dolientes y profundos suspiros, que parecía que con cada uno se le arrancaba el alma (I, XLIII).

\section{Segunda Parte}

[recuerda bien] cómo te recibe: [...] si no cabe en la almohada, si acaso la hallas sentada en el estrado rico de su autoridad; y si está en pie, mírala si se pone ahora sobre el uno, ahora sobre el otro pie [..] porque si tú me los relatares como ellos fueron, sacaré yo lo que ella tiene escondido en lo secreto de su corazón (II, X)

ya se había puesto don Quijote de hinojos junto a Sancho, y miraba con ojos desencajados y vista turbada a la que Sancho llamaba reina y señora [una aldeana] (II, X)

[la aldeana] tomó una corridica, y puestas ambas manos sobre las ancas de la pollina, dio con su cuerpo, más ligero que un halcón, sobre la albarda y quedó a horcajadas, como si fuera hombre (II, $\mathrm{X}$ )

Don Quijote se gallardeó en la silla, púsose bien en los estribos (II, XXX)

Cuando subieres a caballo, no vayas echando el cuerpo sobre el arzón postrero, ni lleves las piernas tiesas y tiradas y desviadas de la barriga del caballo, ni tampoco vayas tan flojo, que parezca que vas sobre rucio; que el andar a caballo a unos hace caballeros; a otros caballerizos (II, XLIII)

Apeáronse de sus bestias amo y mozo, y acomodándose a los troncos de los árboles, Sancho, que había merendado aquel día, se dejó entrar de rondón por las puertas del sueño (I, LX). 